\title{
Methods of effective use of multimedia applications in innovative educational process
}

\section{Shahlo VALIYEVA ${ }^{1}$}

Namangan State University

\section{ARTICLE INFO}

\section{Article history:}

Received January 2021

Received in revised form

15 January 2021

Accepted 20 February 2021

Available online

7 March 2021

\section{Keywords:}

Teaching English

Multimedia

E-learning

Animation

Video application.

\section{ABSTRACT}

There is enormous influence of technology on the ELT world, it is important to look at how to teach and, especially digital technology can support EFL teaching. There is so much digital technology out there nowadays for teachers to integrate into teaching process to support and enhance language learning. However, there's no denying that today our education has still evolved from a pen, paper and textbook affairs to using smart boards, iPads, online multimedia resources and even mobile applications. There are such effective ways of blending technology in EFL your classroom. This article analyzes the ways of using multimedia applications in the educational process and their importance in the teaching and learning process.

2181-1415/CC 2021 in Science LLC.

This is an open access article under the Attribution 4.0 International (CC BY 4.0) license (https://creativecommons.org/licenses/by/4.0/deed.ru)

\section{Innovatsion ta'lim jarayonida multimediya ilovalaridan samarali foydalanish usullari}

\author{
Калит сўзлар: \\ Ingliz tilini o'qitish \\ Multimedia \\ Elektron o'quv \\ Animatsiya \\ Video dastur.
}

\begin{abstract}
АННОТАЦИЯ
Ingliz tili o'qitishda zamonaviy texnologiyalarning ulkan ta'siri mavjud bo'lib, chet tilini qanday o'qitish kerakligi va ayniqsa raqamli texnologiyalar orqali ingliz tilini samarali o'qitish mumkinligiga e'tibor qaratish lozim. Hozirgi kunda o'qituvchilar tilni o'qtish va uni rivojlantirish uchun o'quv jarayonida foydalanishi mumkin bo'lgan ko'p raqamli texnologiyalar mavjud. Biroq, bugungi kunda ta'lim jarayonida qalam, qog'oz va darsliklari bilan birga smart doskalar, iPad, onlayn multimedia resurslari va xattoki mobil dasturlardan foydalanishga qadar rivojlanib kelganligini inkor eta olmaymiz. Sinfda ingliz tilini o'qitishda zamonaviy texnologiyalarni
\end{abstract}

\footnotetext{
${ }^{1}$ Lecturer, Namangan State University, Namangan, Uzbekistan

E-mail: shahlovaliyeva@mail.ru
} 
integratsiyalashuvining samarali usullari mavjud. Ushbu maqolada multimedia dasturlaridan ta'lim jarayonida foydalanish usullari va ularning ta'lim va tarbiya jarayonidagi ahamiyati tahlil qilingan

\section{Методы эффективного использования мультимедийных приложений в инновационном образовательном процессе}

\author{
Ключевые слова: \\ Обучение английскому \\ языку \\ Мультимедиа \\ Электронное обучение \\ Анимация \\ Видеоприложение
}

\begin{abstract}
АННОТАЦИЯ
Технологии оказывают огромное влияние на мир ELT, важно понимать, как преподавать, и, особенно, цифровые технологии могут поддержать преподавание английского языка как иностранного. В настоящее время существует так много цифровых технологий, которые учителя могут интегрировать в учебный процесс для поддержки и улучшения изучения языка. Однако нельзя отрицать, что сегодня наше образование все еще эволюционировало от ручки, бумаги и учебников до использования умных досок, iPad, онлайн-мультимедийных ресурсов и даже мобильных приложений. Есть такие эффективные способы смешивания технологий в EFL в вашем классе. В статье анализируются способы использования мультимедийных приложений в учебном процессе и их значение в процессе преподавания и обучения.
\end{abstract}

Open access to modern knowledge, effective use of pedagogical technologies to improve education is one of the main requirements of our time. According to the law of education of the Republic of Uzbekistan "The material and technical base and educational base of educational institutions will be strengthened. The educational process will be provided with high-quality educational literature and advanced pedagogical technologies." The rapid penetration of information and communication technologies into the education sector, in turn, contributes to the organization of the educational process, the development of educational and methodological support, an increase in the efficiency of mastering subjects and an increase in the level of knowledge of students. The use of information and communication technologies, the use of multimedia technologies in the classroom, the ability of students to fully understand and visualize a topic in the learning process is also facilitated by the organization of the educational process in secondary schools, academic lyceums and professional colleges.

The concept of multimedia is broad, and experts in different fields try to interpret it differently depending on the content. The most common state of the concept of multimedia (multimedia tools) is software and hardware for creating, creating, digitizing, texting, drawing, diagrams, photographs, video and audio recordings, and more. Multimedia is a set of hardware and software that allows a person to communicate with a computer using a variety of natural environments: sound, video, graphics, text and animation. The most important feature of multimedia technology is the ability to interact with the user in an interactive environment. The use of these technologies in the educational process can visually illustrate the subject being studied and allow children to visualize and retain 
memory through visual effects. During the learning process, the student's attention is often subdivided and he or she takes a certain part of the assimilated material. If the lessons are taught using multimedia applications and the topics are explained by national heroes, then the lessons that are taught in mathematics, English and Russian will be much higher. He quickly finds out what the hero is saying and tries to imitate it. The creation of these applications does not require a lot of responsibility from the teacher. At the initial stage of designing a multimedia application, the coverage model will allow:

1. Accuracy of material content;

2. Presentation of content in a clear, clear and concise manner;

3. Define the content of the multimedia components of the application

Multimedia applications are divided into the following types:

- Presentations;

- Animated clips;

- Games;

- Video clips;

- Multimedia galleries;

- Audio applications;

In recent years, many multimedia software products have been created and are being developed: encyclopedias, educational programs, computer presentations and much more. Multimedia textbooks are textbooks that expand access to information and educational resources using multimedia technologies and are the most effective way to create educational resources in the learning process. Multimedia applications can be created as follows:

- Encyclopedias;

- Educational programs;

- Programs for the development of consciousness;

- E-books;

- Children's programs;

- Games and much more.

The multimedia application consists of a variety of themes using themed animation effects in the design of the themes that are the basis for organizing the lesson. Multimedia applications can also be used in teaching professional subjects. There are also video tutorials to teach students how to knit, sew and make cookies. The development of multimedia applications is carried out in several stages, the main of which are:

1. Planning

2. Development of elements

3. Software.

4. Verification

5. Advertising

6. Advertising

7. Observation

The introduction of modern e-learning into educational processes provides the in following:

- the student acquires professional knowledge;

- In-depth study of science by modeling the studied events and processes; 
- expansion of the scope of independent student activities through various organization of educational activities; individualization and differentiation of the learning process based on the introduction of interactive communication capabilities;

- master the strategy of mastering educational materials using the capabilities of the artificial intelligence system;

- Formation of information culture as a member of the information society;

- It is important to present the processes and phenomena studied using computer technology, which will increase the interest and activity of students in the basics of science.

Multimedia products are one of the main educational technologies for organizing the educational process and the use of multimedia technologies, which helps to develop the imagination, knowledge, skills and abilities of students and is one of the most important methods. While technological advances can make teaching and learning all the more exciting for those who are willing to experiment and think outside of the lecture podium, and years from now, educators may very well look to this generation of teachers as the pioneers of technology enhanced learning. By educating yourself on how to best utilize technology in your classroom, you'll help expand your students' learning while also showing your employer that you're able to use technology effectively and creatively, making you a more valuable hire in a currently unstable job market.

\section{References:}

1. A. Parpiev, A. Marakhimov, R. Khamdamov, U. Begimkulov, M. Bekmuradov, N. Tylokov. Electronic University. Distance learning technologies. For universities / State Scientific Publishing House of Uzbekistan.

2. A.Kh.Nishonov and others. Free and open source software, information technology and telecommunications, Republican Scientific and Technical Conference, Tashkent, 2012.

3. Sarimsakova, D. (2020, December). The models of communicative competence: developing sociolinguistic competence in EFL teaching. In Конференции.

4. Muhamadjonovna, S. D. (2020). A Set Of Methodological Tools For The Formation Of Sociolinguistic Competence Of Future English Teachers. The American Journal of Social Science and Education Innovations, 2(12), 298-302.

5. Sarimsakova, D. (2017). Station Rotation. English Teaching Professional, 109. 